medRxiv preprint doi: https://doi.org/10.1101/2020.04.26.20079988; this version posted May 1,2020 . The copyright holder for this preprint (which was not certified by peer review) is the author/funder, who has granted medRxiv a license to display the preprint in perpetuity. It is made available under a CC-BY 4.0 International license.

Instituto Nacional de Ciencias Médicas y Nutrición

"Salvador Zubirán". MEXICO

(Mexico City, April 10, 2020)

\title{
Methods of An Open-Label Proof-Of-Concept Trial of Intravenous Valproic Acid for Severe COVID- 19
}

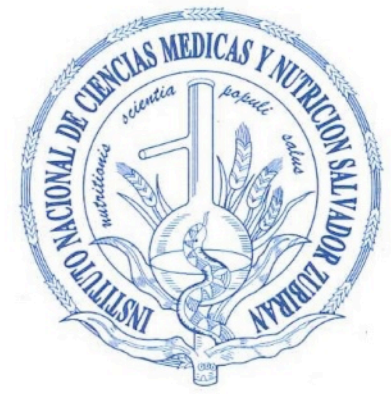

INSTITUTO NACIONAL DE CIENCIAS MÉDICAS Y N U T R I C I Ó N SALVADOR ZUBIRÁN

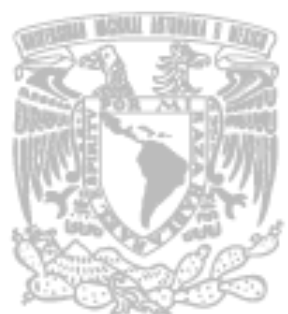

UNIVERSIDAD NACIONAL AUTÓNOMA DE MÉXICO 
medRxiv preprint doi: https://doi.org/10.1101/2020.04.26.20079988; this version posted May 1, 2020. The copyright holder for this preprint (which was not certified by peer review) is the author/funder, who has granted medRxiv a license to display the preprint in perpetuity. It is made available under a CC-BY 4.0 International license .

\section{[TITLE PAGE]}

Full Title: Methods of An Open-Label Proof-Of-Concept Trial of Intravenous Valproic Acid for Severe COVID-19

Cover Title: A Trial of Intravenous Valproic Acid for Severe COVID-19

Authors: Erwin Chiquetea , Liz Toapanta-Yanchapaxia, Carlos Cantú-Brito ${ }^{a}$

${ }^{a}$ Neurology and Psychiatry Department. Instituto Nacional de Ciencias Médicas y Nutrición "Salvador Zubirán". Mexico City, Mexico.

Number of tables: 0

Number figures: I

Number of figures: I

Characters count in title: 96

Abstract word count: 254

Text word count: 1680

Number of references: 25 
medRxiv preprint doi: https://doi.org/10.1101/2020.04.26.20079988; this version posted May 1, 2020. The copyright holder for this preprint (which was not certified by peer review) is the author/funder, who has granted medRxiv a license to display the preprint in perpetuity. It is made available under a CC-BY 4.0 International license .

\section{[AUTHORS INFORMATION PAGE]}

\section{Methods of An Open-Label Proof-Of-Concept Trial of Intravenous \\ Valproic Acid for Severe COVID- 19}

Erwin Chiquetea, Liz Toapanta-Yanchapaxi ${ }^{\mathrm{a}}$, Carlos Cantú-Brito ${ }^{\mathrm{a}}$

${ }^{a}$ Neurology and Psychiatry Department. Instituto Nacional de Ciencias Médicas y Nutrición "Salvador Zubirán". Mexico City, Mexico. 
medRxiv preprint doi: https://doi.org/10.1101/2020.04.26.20079988; this version posted May 1, 2020. The copyright holder for this preprint (which was not certified by peer review) is the author/funder, who has granted medRxiv a license to display the preprint in perpetuity.

\section{Corresponding authors:}

Dr. Erwin Chiquete. Departamento de Neurología y Psiquiatría. Instituto Nacional de Ciencias Médicas y Nutrición Salvador Zubirán. Avenida Vasco de Quiroga No. 15, Colonia

Belisario Domínguez Sección XVI, Delegación Tlalpan C.P.I4080. Ciudad de México. México. E-mail: erwinchiquete@hotmail.com. Tel: +52 54247200 ext. 4I77.

\section{Competing conflicts of interest / Disclosures:}

The authors have no relevant conflicts of interest to declare.

\section{Source of funding:}

The Instituto Nacional de Ciencias Médicas y Nutrición Salvador Zubirán and CONACyT will sponsor this proof-of-concept interventional study. A larger clinical trial, in case of success of this pilot study, will have several sources of sponsorship. 
medRxiv preprint doi: https://doi.org/10.1101/2020.04.26.20079988; this version posted May 1,2020 . The copyright holder for this preprint (which was not certified by peer review) is the author/funder, who has granted medRxiv a license to display the preprint in perpetuity.

\section{[ABSTRACT]}

Introduction: Coronavirus disease 2019 (COVID-19) is the systemic entity caused by the severe acute respiratory syndrome coronavirus 2 (SARS-CoV-2) that may cause death through severe atypical pneumonia and acute lung injury. Valproic acid (VPA) has shown anti-inflammatory activity and mild intrinsic antiviral effect. These properties warrant the study of VPA as a possible active treatment in persons with severe COVID-19.

Methods: Consecutive adult patients needing invasive mechanical ventilation (IMV) will be given intravenous (i.v.) VPA at a starting dose of $20 \mathrm{mg} / \mathrm{kg} /$ day and up to $60 / \mathrm{kg} /$ day (in $60 \mathrm{~min}$ i.v. infusions in $250 \mathrm{~mL}$ normal saline) as needed to reach plasma VPA concentrations of 50$100 \mu \mathrm{g} / \mathrm{mL}$ (measured every $72 \mathrm{~h}$ ). These patients will be followed-up for 10 days for the primary outcome and for a further period of 30 days after treatment completion for the secondary outcome of recurrence. The primary study outcome is the reduction in the case fatality rate of at least $50 \%$ after 10 days of treatment (as compared with natural history). Secondary outcomes are the reduction of length of stay (LOS) of at least $50 \%$, as well as COVID-19 recurrence at 30-day follow-up. The most important safety outcomes are acute liver failure, acute pancreatitis, and thrombocytopenia.

Conclusion: Although long-term adverse effects and even pro-inflammatory consequences have been reported with the chronic use of VPA, given the urgent need for a drug against COVID-19 to shorten the high mortality and LOS, the study of VPA is justified from a scientific standpoint.

Keywords: Atypical pneumonia, coronavirus, COVID-19, Mexico, pandemics, valproate, valproic acid. 
medRxiv preprint doi: https://doi.org/10.1101/2020.04.26.20079988; this version posted May 1,2020 . The copyright holder for this preprint (which was not certified by peer review) is the author/funder, who has granted medRxiv a license to display the preprint in perpetuity.

\section{Introduction}

Coronavirus disease 2019 (COVID-19) is the systemic disease caused by the severe acute respiratory syndrome coronavirus 2 (SARS-CoV-2) that may cause death through severe atypical pneumonia and acute lung injury. There is a need for useful molecules that may cut the rate of deaths and hospital length of stay (LOS) that produce such a high sanitary burden. Given the urgent need for high-efficacy drugs, repurposed molecules may be the most efficient approach given the scarce time to limit the sanitary and economic impact of the present pandemics.

Valproic acid (VPA, the conjugate base is valproate) is available as sodium, semi sodium, and magnesium. VPA is a drug primarily used to treat epilepsy, bipolar disorder, as well as migraine.' Chemically VPA is a weak organic acid that was first synthesized in 1882 as an analog of valeric acid, found naturally in the plant valeriana officinalis. ${ }^{1,2}$ VPA was tested initially as a solvent of organic compounds, and latter found serendipitously to be active in animals and humans as an anticonvulsant in $1962 .{ }^{3}$ It is a carboxylic acid clear liquid at room temperature. VPA was first approved in France (1967) for use in humans as an anti-epileptic medication. ${ }^{\prime}$

VPA attenuates the expression of pro-inflammatory cytokines in preclinical models ${ }^{4-9}$ and in humans ${ }^{10,11}$ especially during the acute treatment phase, although conflicting results have been reported. ${ }^{12}$ This molecule has also shown intrinsic antiviral activity probably due to its activity as histone deacetylase inhibitor. ${ }^{9,13-16}$ VPA has shown anti-inflammatory activity in myocardial ${ }^{17}$ as well as neural tissue in models of brain and spinal cord injuries, ${ }^{18,19}$ although with some conflicting findings. ${ }^{20}$

Although long-term adverse effects and even pro-inflammatory consequences have been reported with the chronic use of VPA, ${ }^{12}$ we believe that, given the urgent need to have 
medRxiv preprint doi: https://doi.org/10.1101/2020.04.26.20079988; this version posted May 1, 2020. The copyright holder for this preprint (which was not certified by peer review) is the author/funder, who has granted medRxiv a license to display the preprint in perpetuity.

It is made available under a CC-BY 4.0 International license .

a useful drug to shorten the high mortality and LOS associated with COVID-19,,$^{21,22}$ the study of the safety and efficacy of VPA in the treatment of COVID-19 is warranted from a scientific standpoint.

\section{Methods}

\section{Study type}

Open-label proof-of-concept interventional study.

\section{Hypothesis}

Intravenous valproic acid will be safe and effective in the treatment of patients with severe COVID-19.

\section{Intervention}

Sodium valproic acid will be given intravenously at a starting dose of $20 \mathrm{mg} / \mathrm{kg} / \mathrm{day}$ and up to $60 / \mathrm{kg} /$ day as needed to reach plasma valproic acid concentration of $50-100 \mu \mathrm{g} / \mathrm{mL}$ (measured every $72 \mathrm{~h}$ ). Three equal doses per day given intravenously in infusions lasting $60 \mathrm{~min}$ in 250 $\mathrm{mL}$ normal saline.

\section{Study oversight and ethical considerations}


medRxiv preprint doi: https://doi.org/10.1101/2020.04.26.20079988; this version posted May 1, 2020. The copyright holder for this preprint (which was not certified by peer review) is the author/funder, who has granted medRxiv a license to display the preprint in perpetuity. It is made available under a CC-BY 4.0 International license .

Ten days of i.v. treatment for the primary outcome, plus 30 days for the secondary outcome of COVID-19 recurrence, given a total of 40 days of follow-up.

\section{Population}

Patients admitted with severe COVID-I9 to the ICU of the Instituto Nacional de Ciencias Médicas y Nutrición Salvador Zubirán (INCMNSZ).

\section{Main study outcomes}

Primary outcomes:

- Reduction in a case fatality rate (CFR) of at least $50 \%$, from a known proportion of $40 \%$ to $20 \%$ after 10 days of treatment.

Secondary exploratory outcomes:

- Reduction of length of stay (LOS) of at least $50 \%$, from a known median LOS of 10 days to 5 days after at least 5 days of i.v. valproic acid exposition.

- No COVID-19 recurrence during a 30-day observational period, after completion of the I0-day i.v. therapy.

\section{Selection criteria}

Inclusion criteria: 
medRxiv preprint doi: https://doi.org/10.1101/2020.04.26.20079988; this version posted May 1, 2020. The copyright holder for this preprint (which was not certified by peer review) is the author/funder, who has granted medRxiv a license to display the preprint in perpetuity.

It is made available under a CC-BY 4.0 International license .

- Patients aged $>18$ years

- Both sexes

- Positive to SARS-CoV-2 RNA in nasopharyngeal samples by RT-PCR

- Severe acute respiratory syndrome treated with IMV at study recruitment

- Any time elapsed since symptoms onset to study recruitment

- Any length of hospital stay

- Any length of IMV

- Signed informed consent from patient or legal proxy

- No known VPA allergy

- Patients with or without previous or current exposure to anti-epileptics

- Patients with or without previous or current exposure to chloroquine,

hydroxychloroquine or azythromicin

- Patients not participating in an interventional trial

- Patients not under current valproate treatment

- Patients not under current treatment with remdesivir

- Patients not under current treatment with tocilizumab

Exclusion criteria:

- Decline of informed consent

- Signs of VPA allergy

- Any acute severe side effect (either thrombocytopenia, acute liver disease, moderateto-severe hypertransaminasemia, or acute pancreatic injury)

- Incomplete information for primary outcome *

*Intention-to-treat analysis (ITT) will be performed, considering study dropouts as failures. 
medRxiv preprint doi: https://doi.org/10.1101/2020.04.26.20079988; this version posted May 1,2020 . The copyright holder for this preprint (which was not certified by peer review) is the author/funder, who has granted medRxiv a license to display the preprint in perpetuity.

\section{Recruitment strategy}

Consecutive patients needing IMV and meeting selection criteria will be given i.v. valproic acid for 10 days maintaining a plasma concentration of $50-100 \mu \mathrm{g} / \mathrm{mL}$ (measured every $72 \mathrm{~h}$ ). These patients will be followed-up for 10 days for the primary outcome and for a further period of 30 days after treatment completion.

\section{Safety outcomes}

The most important acute side effects of valproic acid that should be meticulously on a daily basis examined are:

- Acute liver failure, defined as the severe acute liver injury with encephalopathy and impaired synthetic function (international normalized ratio $\geq 1.5$ ) in a subject free of preexistent chronic liver disease.

- Acute pancreatitis, defined as the American Gastroenterological Association (AGA) ${ }^{23}$ guidelines: the presence of two out of three of the following characteristics: a) abdominal pain consistent with the disease, b) serum amylase and/or lipase activity $>3$ times the upper limit of normal, and c) characteristic findings on abdominal imaging.

- Thrombocytopenia, defined as the platelet blood count $<50,000$ per $\mu \mathrm{L}$.

- Hypertransaminasemia, defined as the elevation of alanine transaminase (ALT) and/or aspartate transaminase (AST) activity in serum, $>3$ times the upper normal limit of the laboratory reference. 
medRxiv preprint doi: https://doi.org/10.1101/2020.04.26.20079988; this version posted May 1,2020 . The copyright holder for this preprint (which was not certified by peer review) is the author/funder, who has granted medRxiv a license to display the preprint in perpetuity.

As stated in the selection criteria, patients with the current use of anti-epileptics are allowed to be recruited, criteria that may include patients with epilepsy. In case of the need of other anti-epileptics to treat new or recurrent seizures, the inclusion of such medications will be a prerogative of the treating physician team. The investigational team of this trial will reinforce the maintenance of the patient in the study, by helping in the selection of anti-epileptics with no known adverse interactions with VPA, but in any particular case of perceived harm that may arise with the interaction of VPA with other anti-epileptics, the patient will be removed from the study.

\section{Study duration}

Ten days of i.v. treatment for the primary outcome, plus 30 days for the secondary outcome of COVID-19 recurrence, given a total of 40 days of follow-up.

\section{Major statistical hypothesis}

There will be at least a $50 \%$ reduction of death of patients with severe COVID-19 needing invasive mechanical ventilation (IMV).

\section{Sample size}

This is a proof-of-concept study, therefore, sample size calculation was performed by using the formula for the difference of proportions with a known (previous) proportion, and 
medRxiv preprint doi: https://doi.org/10.1101/2020.04.26.20079988; this version posted May 1,2020 . The copyright holder for this preprint (which was not certified by peer review) is the author/funder, who has granted medRxiv a license to display the preprint in perpetuity.

assuming a high magnitude of the efficacy of the study drug, since, given the contingency of this pandemics, minor effect sizes reductions are not desirable.

According to the most extensive information available today on I,59I Italian patients with severe COVID-19 admitted to ICU, ${ }^{24}$ it is expected a $40 \%$ CFR final disposition of patients, according to Bayesian analysis (the original information reports $26 \%$ CFR, but $58 \%$ of patients still in ICU as of the analysis deadline of March 25, 2020). Hence, the sample size was calculated to detect a minimum of (but not restricted to) $50 \%$ reduction in the CFR from $40 \%$ to $20 \%$, with $80 \%$ study power and $5 \%$ type I error.

Therefore, a sample size of at least (but not restricted to) 43 patients will be needed to demonstrate an absolute (not RRR) reduction of $50 \%$ in CFR. No excess sample size was considered to cover study losses since ITT analysis requires that drop-outs are considered as failures to achieve study outcomes.

\section{Statistical plan}

ITT analyses will be performed considering all patients removed from the study for any reason as treatment failures. Per protocol (PP) analyses will also be performed considering in the calculations only patients with complete information and complete treatment schemes, but the analyses on the PP population will only be considered as hypothesis-generating to further pursue the study objectives with another robust design. Daily patients inspections will be performed in order to demonstrate first that valproic acid is not harmful, to review plasma levels (measured every $72 \mathrm{~h}$ ), and clinical response. With this information, on a daily basis, statistical analyses will be performed for outcome differences by using chi-squared tests for categorical variables and hazard ratios to obtain effect sizes of study outcomes 
medRxiv preprint doi: https://doi.org/10.1101/2020.04.26.20079988; this version posted May 1,2020 . The copyright holder for this preprint (which was not certified by peer review) is the author/funder, who has granted medRxiv a license to display the preprint in perpetuity.

(primary and secondary outcomes), as well as safety outcomes. After completion of the study (either as per protocol or prematurely terminated), actuarial analyses with the KaplanMeier method will be performed for each study outcome to illustrate effect differences. All analyses performed will be two-tailed and wondered as significant when $\mathrm{p}<0.05$.

\section{Interim analyses and termination rules}

This study will be terminated as per protocol when at least 43 patients complete 10 days of i.v. valproic acid therapy.

Premature termination will be executed when the following events occur:

- Since only a high effect size (>50\%) in reducing death will be considered worthwhile to pursue further clinical study on valproic acid activity on COVID-19, the outcome rate boundary to terminate prematurely this proof-of-concept study will be 10 deaths occurred in ventilated patients.

- A rate of acute side effects (either thrombocytopenia, acute liver disease or acute pancreatic injury) exceeding 4 cases (10\% event rate) will be considered unacceptable and will lead to premature termination, given that this rate exceeds the expected, given the current information on critically-ill patients exposed to valproic acid to treat epilepsy and status epilepticus.

\section{Conclusions}

It is necessary for a useful drug to treat COVID-19 and its consequences. Given that it is expected the duration of a long-lasting pandemic, ${ }^{25}$ it can be supposed that we will have 
medRxiv preprint doi: https://doi.org/10.1101/2020.04.26.20079988; this version posted May 1,2020 . The copyright holder for this preprint (which was not certified by peer review) is the author/funder, who has granted medRxiv a license to display the preprint in perpetuity.

several ways to treat this disease, to improve several clinical outcomes of importance to eventually stop the direct sanitary implications and the very high economic burden that the COVId-19 pandemics has caused. Although long-term adverse effects and even proinflammatory consequences have been reported with the chronic use of VPA, given the urgent need for a drug active against COVID-19 to shorten the high mortality and LOS, the study of VPA is justified from a scientific standpoint.

\section{Acknowledgements}

The authors are grateful to the authorities, colleagues, and patients of Instituto Nacional de Ciencias Médicas y Nutrición Salvador Zubirán for their support to perform this trial, as well as the grants of possible donors that are currently evaluating this investigation idea.

\section{References}

I. Löscher W. Basic pharmacology of valproate: a review after 35 years of clinical use for the treatment of epilepsy. CNS Drugs. 2002;16(10):669-94.

2. Henry TR. The history of valproate in clinical neuroscience. Psychopharmacol Bull. 2003;37 Suppl 2:5-16.

3. Terbach N, Williams RS. Structure-function studies for the panacea, valproic acid. Biochem Soc Trans 2009; 37: II26-32.

4. Amirzargar MA, Yaghubi F, Hosseinipanah M, Jafari M, Pourjafar M, Rezaeepoor $M$, et al. Anti-inflammatory Effects of Valproic Acid in a Rat Model of Renal Ischemia/Reperfusion Injury: Alteration in Cytokine Profile. Inflammation. 2017 Aug;40(4):13 I0-13 I8. doi:10.1007/s 10753-0I7-0574-9.

5. Hoşgörler F, Keleş D, Tanrıverdi-Akhisaroğlu S, İnanç Ş, Akhisaroğlu M, Cankurt Ü, et al. 
medRxiv preprint doi: https://doi.org/10.1101/2020.04.26.20079988; this version posted May 1, 2020. The copyright holder for this preprint (which was not certified by peer review) is the author/funder, who has granted medRxiv a license to display the preprint in perpetuity.

Anti-inflammatory and Anti-apoptotic Effect of Valproic Acid and Doxycycline Independent from MMP Inhibition in Early Radiation Damage. Balkan Med J. 2016 Sep;33(5):488-495.

6. Delgado FG, Cárdenas P, Castellanos JE. Valproic Acid Downregulates Cytokine Expression in Human Macrophages Infected with Dengue Virus. Diseases. 2018 Jul 6;6(3). pii: E59. doi: 10.3390/diseases6030059.

7. Seet LF, Toh LZ, Finger SN, Chu SWL, Wong TT. Valproic acid exerts specific cellular and molecular anti-inflammatory effects in post-operative conjunctiva. J Mol Med (Berl). 2019 Jan;97(I):63-75. doi: 10.1007/s00 I09-018-1722-x.

8. Kasotakis G, Galvan MD, Osathanugrah P, Dharia N, Bufe L, Breed Z, et al. Timing of valproic acid in acute lung injury: prevention is the best therapy? J Surg Res. 2017 Dec;220:206-2I2. doi: 10.1016/j.jss.2017.06.088.

9. Soria-Castro R, Schcolnik-Cabrera A, Rodríguez-López G, Campillo-Navarro M, PueblaOsorio N, Estrada-Parra S, et al. Exploring the Drug Repurposing Versatility of Valproic Acid as a Multifunctional Regulator of Innate and Adaptive Immune Cells. J Immunol Res. 2019 Mar 14;2019:9678098. doi: I0.1 I55/2019/9678098.

10. Steinborn B, Zarowski M, Winczewska-Wiktor A, Wójcicka M, MłodzikowskaAlbrecht J, et al. Concentration of II-I $\beta, \|-2, I \mid-6, T N F \alpha$ in the blood serum in children with generalized epilepsy treated by valproate. Pharmacol Rep. 2014 Dec;66(6):972-5. doi: 10.1016/j.pharep.2014.06.005.

II. Sonmez FM, Serin HM, Alver A, Aliyazicioglu R, Cansu A, Can G, et al. Blood levels of cytokines in children with idiopathic partial and generalized epilepsy. Seizure. 2013 Sep;22(7):517-2I. doi: 10.1016/j.seizure.2013.03.014.

12. Shiah IS, Yatham LN, Yeh CB, Ravindran AV. Effect of valproate on plasma levels of interleukin-6 in healthy male humans. Int Clin Psychopharmacol. 2005 Nov;20(6):295-8. 
medRxiv preprint doi: https://doi.org/10.1101/2020.04.26.20079988; this version posted May 1, 2020. The copyright holder for this preprint (which was not certified by peer review) is the author/funder, who has granted medRxiv a license to display the preprint in perpetuity.

13. Crespillo AJ, Praena B, Bello-Morales R, Lerma L, Vázquez-Calvo A, Martín-Acebes MA, et al. Inhibition of herpes virus infection in oligodendrocyte cultured cells by valproic acid. Virus Res. 2016 Mar 2;214:7I-9. doi: 10.1016/j.virusres.2016.01.009.

14. Vázquez-Calvo A, Saiz JC, Sobrino F, Martín-Acebes MA. Inhibition of enveloped virus infection of cultured cells by valproic acid. J Virol. 20I I Feb;85(3):I267-74. doi: 10.1 I28/JVI.0I7I7-10.

15. Vázquez-Calvo Á, Martín-Acebes MA, Sáiz JC, Ngo N, Sobrino F, de la Torre JC. Inhibition of multiplication of the prototypic arenavirus LCMV by valproic acid. Antiviral Res. 2013 Aug;99(2):172-9. doi: 10.1016/j.antiviral.2013.05.012.

16. Praena B, Bello-Morales R, de Castro F, López-Guerrero JA. Amidic derivatives of valproic acid, valpromide and valnoctamide, inhibit HSV-I infection in oligodendrocytes. Antiviral Res. 2019 Aug;168:91-99. doi:10.1016/j.antiviral.2019.05.006.

17. Jin H, Guo X. Valproic acid ameliorates coxsackievirus-B3-induced viral myocarditis by modulating Th I7/Treg imbalance. Virol J. 2016 Oct 10;13(I):168.

18. Chen S, Ye J, Chen X, Shi J, Wu W, Lin W, et al. Valproic acid attenuates traumatic

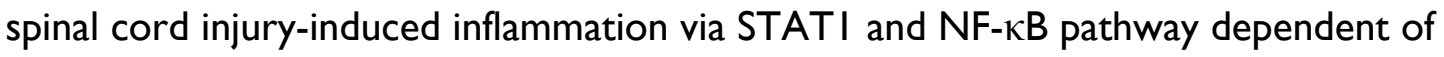
HDAC3. J Neuroinflammation. 2018 May 18;15(I):150.doi:

19. Chen X, Wang H, Zhou M, Li X, Fang Z, Gao H, et al. Valproic Acid Attenuates Traumatic Brain Injury-Induced Inflammation in Vivo: Involvement of Autophagy and the Nrf2/ARE Signaling Pathway. Front Mol Neurosci. 2018 Apr 17; I I: I 17. doi:

10.3389/fnmol.2018.00117.

20. Dambach H, Hinkerohe D, Prochnow N, Stienen MN, Moinfar Z, Haase CG, Hufnagel A, Faustmann PM. Glia and epilepsy: experimental investigation of antiepileptic drugs in an astroglia/microglia co-culture model of inflammation. Epilepsia. 2014 Jan;55(I):I84-92. doi: I0.I I I I/epi. I 2473. 
medRxiv preprint doi: https://doi.org/10.1101/2020.04.26.20079988; this version posted May 1,2020 . The copyright holder for this preprint (which was not certified by peer review) is the author/funder, who has granted medRxiv a license to display the preprint in perpetuity. It is made available under a CC-BY 4.0 International license .

21. Noël Fa, Lima J. Pharmacological aspects and clues for the rational use of

Chloroquine/Hydroxychloroquine facing the therapeutic challenges of COVID-19 pandemic. Lat Am J Clin Sci Med Technol. 2020 Apr; 2: 28-34.

22. Zuluaga AF, Rodriguez CA, Montoya-Giraldo MA. Which is the pharmacodynamic target to calculate a rational dose against SARS-Cov-2? Lat Am J Clin Sci Med Technol. 2020 Apr; 2: 35-37.

23. Crockett SD, Wani S, Gardner TB, Falck-Ytter Y, Barkun AN; American Gastroenterological Association Institute Clinical Guidelines Committee. American Gastroenterological Association Institute Guideline on Initial Management of Acute Pancreatitis. Gastroenterology. 2018 Mar; I54(4):I096-I I0I.

24. Grasselli G, Zangrillo A, Zanella A, Antonelli M, Cabrini L, Castelli A, et al. Baseline Characteristics and Outcomes of I59I Patients Infected With SARS-CoV-2 Admitted to ICUs of the Lombardy Region, Italy. JAMA. 2020 Apr 6. doi: 10.100 I/jama.2020.5394. [Epub ahead of print]

25. Kissler SM, Tedijanto C, Goldstein E, Grad YH, Lipsitch M. Projecting the transmission dynamics of SARS-CoV-2 through the postpandemic period. Science. 2020 Apr 14. pii: eabb5793. doi: 10.1 I26/science.abb5793. 
medRxiv preprint doi: https://doi.org/10.1101/2020.04.26.20079988; this version posted May 1, 2020. The copyright holder for this preprint (which was not certified by peer review) is the author/funder, who has granted medRxiv a license to display the preprint in perpetuity.

It is made available under a CC-BY 4.0 International license.

\section{[Figure legends]}

Figure. Diagrammatic study outline: methods of an open-label proof-of-concept trial of intravenous valproic acid for severe COVID-I9. 
medRxiv preprint doi: https://doi.org/10.1101/2020.04.26.20079988; this version posted May 1, 2020. The copyright holder for this preprint (which was not certified by peer review) is the author/funder, who has granted medRxiv a license to display the preprint in perpetuity. It is made available under a CC-BY 4.0 International license.

\section{[Figure]}

\section{VPA in severe COVID- I 9 \\ a proof-of-concept trial}

Adults with COVID-19 needing IVM

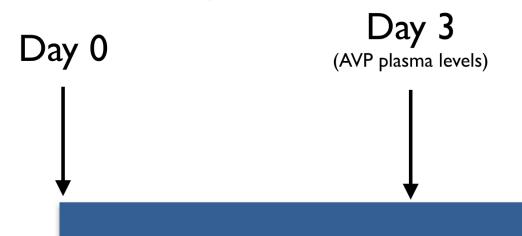

\section{Follow-up}

Daily follow-up clinical examinations

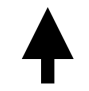

Study initiation
Daily vigilance on safety:

- Acute liver failure

- Acute pancreatitis

- Thrombocytopenia
Day 6

(AVP plasma levels)

(Aves

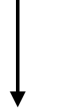

.

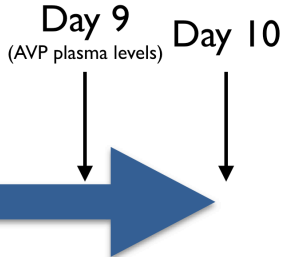

4

Study termination

ITT analysis

* Since only a high effect size in reducing death will be considered worthwhile to pursue further clinical study on valproic acid activity on COVID-19, the outcome rate boundary to terminate prematurely this proof-of-concept study will be 10 deaths occurred in

Primary outcome:

-Case fatality rate ventilated patients. 


\section{VPA in severe COVID- 19 \\ a proof-of-concept trial}

Adults with COVID- 19 needing IVM

Day 0

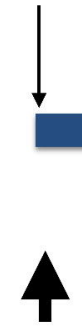

Study initiation
Day 3

(AVP plasma levels)

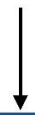

Day 6

(AVP plasma levels)

\section{Follow-up}

Daily follow-up clinical examinations

Daily vigilance on safety:

- Acute liver failure

- Acute pancreatitis

- Thrombocytopenia

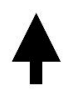

Study termination

* Since only a high effect size in reducing death will be considered worthwhile to pursue further clinical study on valproic acid activity on COVID-19, the outcome rate boundary to terminate prematurely this proof-of-concept study will be 10 deaths occurred in ventilated patients.

ITT analysis

\section{Primary outcome:}

- Case fatality rate

\section{Secondary outcomes:}

-Length of stay 